\title{
Frequency Response of Electronically Tunable Current-Mode Third Order High Pass and Low Pass Filter for $Q=10$
}

\author{
Dr. D. D. Mulajkar \\ S.P. Dnyanasadhana College, Thane, Maharashtra 400604, India
}

\begin{abstract}
The circuits using current-mode (CM) building blocks have received considerable attention in many filtering and signal processing applications. Compared to their voltage-mode(VM) counterparts, the current-mode building blocks are attractive because of their wider bandwidth, higher slew rate, and lower power consumptions. In IC technology, it is desirable to operate circuits at low voltages which can be achieved by using CM building blocks. As a large number of op-amp based circuits with elegant realization procedures are already available, it is worthwhile to convert them into the circuits based on current-mode building blocks. In this paper, a realization of a current mode third order high pass and low pass filter is described. The proposed circuit employs operational amplifier as the basic building unit. The filter circuit realizes quadratic work function. It provides electronically tuning capability of the filter characteristics. The proposed circuit works ideal for Center frequency fo= $10 \mathrm{k}$ and Circuit merit factor $\mathrm{Q}>1$. The gain roll-off this configuration is $18 \mathrm{~dB} /$ octave. The circuit is suitable for monolithic integration and high frequency operation. The filters developed were successful in obtaining passive sensitivities less than unity in magnitude and active sensitivities are half in magnitude, which is a noteworthy achievement. The circuit is suitable for high frequency operation and monolithic integration.
\end{abstract}

KEY WORDS: Current Mode Filter, Center Frequency, Circuit Merit Factor, High Pass, Low Pass, Third Order

\section{INTRODUCTION}

At present, there is a growing interest in designing capacitor-less, resistor-less current mode active only filters using only active elements such as Operational amplifier [OA], Operational trans conductance amplifiers [OTAs]. Current mode filters have many advantages compared with their voltage mode counterparts. Current mode filters have large dynamic range, higher bandwidth, greater linearity, simple circuitry, low power consumption etc. Many circuits for realizing voltage mode filters have been proposed by researchers. The realization of current mode transfer function is topic of considerable interest for researchers. Misami Higashimura proposed a synthesis of current mode high pass transfer function using op-amp pole [Higashimura, 1993]. Extensive work has been done employing active devices such as OAs and OTAs [2, 3]. Due to their many advantages there is growing interest in designing and implementing current mode active filters using second generation current conveyors [CCIIs]. Several implementations of current mode CCII-based filters are available in literature. Current mode active filters are also designed with second generation duel output current conveyors [DO-CCII] [10].

This paper focuses on third order current mode active-R filter with quadratic transfer function.

The proposed circuit is solely designed with op-amps and resistors and hence suitable for highfrequency operation. The filter has low passive sensitivities. The gain roll-off is $40 \mathrm{~dB} / \mathrm{dec}$ ade.

\section{CIRCUIT CONFIGURATION AND ANALYTICAL TREATMENT}

The open loop gain of an OA is represented by the well known first order pole model

$$
\mathrm{A}(\mathrm{S})=\frac{\mathrm{A}_{0} \omega_{0}}{\mathrm{~S}+\omega_{0}}
$$

where $\mathrm{A}_{0}$ : Open loop D.C.gain of op-amp.

$\omega_{0}$ : Open loop $-3 \mathrm{~dB}$ bandwidth of the op-amp $=2 \pi f_{0}$

$A_{0} \omega_{0}: \beta_{i}=$ gain-bandwidth product of op-amp. 


\section{International Journal of Current Science Research and Review}

ISSN: 2581-8341

Volume 04 Issue 10 October 2021

DOI: 10.47191/ijesrr/V4-i10-23, Impact Factor: 5.825

$$
\text { For } \mathrm{S}>>\omega_{0}, \mathrm{~A}(\mathrm{~S})=\frac{\mathrm{A}_{0} \omega_{0}}{\mathrm{~S}}=\frac{\beta \mathrm{i}}{\mathrm{S}}, \quad(\mathrm{i}=1,2,3)
$$

This model of OA is valid from a few $\mathrm{kHz}$ to few hundred $\mathrm{kHz}$.

The transfer function of the circuit for high pass and low pass are

$$
\begin{aligned}
& T_{H P}=\frac{g_{0} S^{3}}{X_{1} S^{3}+X_{2} S^{2}+X_{3} S+X_{4}} \\
& T_{L P}=\frac{g_{2} \beta_{1} \beta_{2} \beta_{3} k_{1} k_{2} k_{3}}{X_{1} S^{3}+X_{2} S^{2}+X_{3} S+X_{4}}
\end{aligned}
$$

Where,

$$
\begin{aligned}
& \mathrm{X}_{1}=\mathrm{g}_{0}+\mathrm{g}_{1}+\mathrm{g}_{2}+\mathrm{g}_{3}+\mathrm{g}_{1 \mathrm{~b}} \mathrm{k}_{1} \\
& \mathrm{X}_{2}=\mathrm{g}_{1} \beta_{1} \mathrm{k}_{1} \\
& \mathrm{X}_{3}=\mathrm{g}_{2} \beta_{1} \beta_{2} \mathrm{k}_{1} \mathrm{k}_{2} \\
& \mathrm{X}_{4}=\mathrm{g}_{3} \beta_{1} \beta_{2} \beta_{3} \mathrm{k}_{1} \mathrm{k}_{2} \mathrm{k}_{3}
\end{aligned}
$$

The circuit was designed using coefficient matching technique i.e. by comparing these transfer functions with general second order transfer functions is given by,

$$
T(S)=\frac{\alpha_{3} S^{3}+\alpha_{2} S^{2}+\alpha_{1} S+\alpha_{0}}{S^{3}+\omega_{0}\left(1+\frac{1}{Q}\right) S^{2}+\omega_{0}^{2}\left(1+\frac{1}{Q}\right) S+\omega_{0}^{3}}
$$

Comparing equations (1), (2) with (3), we get,

$$
\begin{gathered}
\omega_{0}^{3}=\mathrm{g}_{3} \beta_{1} \beta_{2} \beta_{3} \mathrm{k}_{1} \mathrm{k}_{2} \mathrm{k}_{3} \\
\omega_{0}^{2}\left(1+\frac{1}{\mathrm{Q}}\right)=\mathrm{g}_{2} \beta_{1} \beta_{2} \mathrm{k}_{1} \mathrm{k}_{2} \\
\omega_{0}\left(1+\frac{1}{\mathrm{Q}}\right)=\mathrm{g}_{1} \beta_{1} \mathrm{k}_{1} \\
\mathrm{~g}_{0}+\mathrm{g}_{1}+\mathrm{g}_{2}+\mathrm{g}_{3}+\mathrm{g}_{1 \mathrm{~b}} \mathrm{k}_{1}=1
\end{gathered}
$$

But,

$$
g_{1 b} k_{1}<<1
$$

Therefore,

$$
g_{0}+g_{1}+g_{2}+g_{3}=1
$$

Using these equations, the values of $g_{1}, g_{\mathbf{2}}$ and $g_{\mathbf{3}}$ are calculated for different values of merit factor $\mathrm{Q}$ and frequency $\mathrm{f}_{0}$. 
International Journal of Current Science Research and Review

ISSN: 2581-8341

Volume 04 Issue 10 October 2021

DOI: 10.47191/ijcsrr/V4-i10-23, Impact Factor: 5.825

IJCSRR@ 2021

www.ijesrr.org

3. PROPOSED CIRCUIT DIAGRAM:

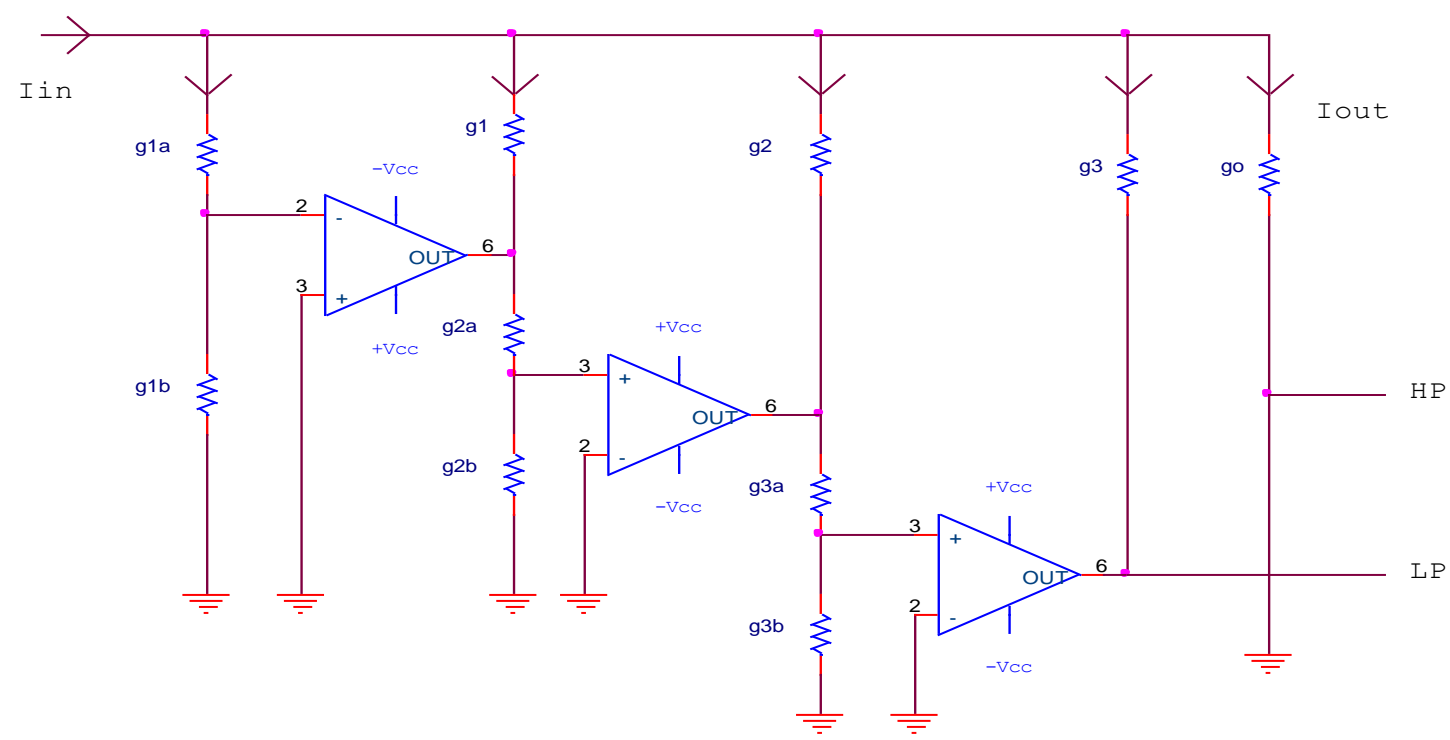

Fig 1. Circuit diagram of third order electronically tunable CM filter

4. LOW PASS RESPONSE

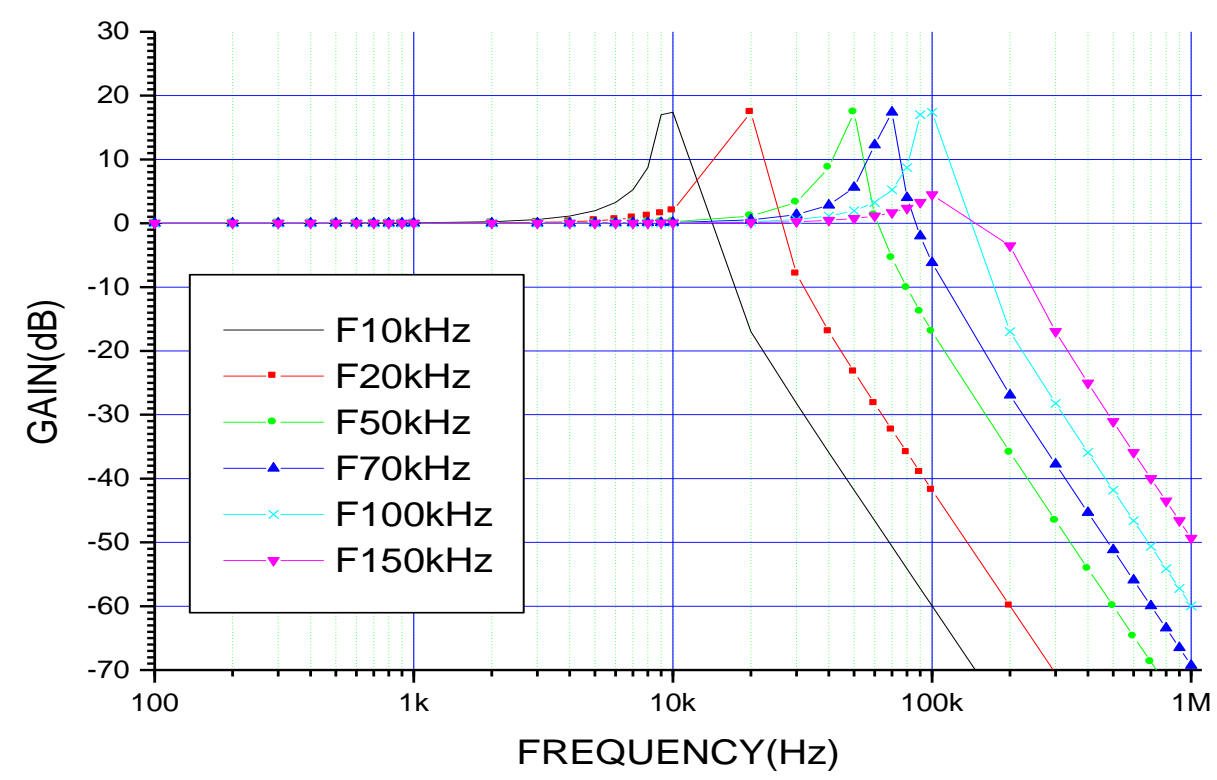

Fig 2. 
International Journal of Current Science Research and Review

ISSN: 2581-8341

Volume 04 Issue 10 October 2021

DOI: 10.47191/ijesrr/V4-i10-23, Impact Factor: 5.825

Table 1: Analysis of Low pass response

\begin{tabular}{|c|c|c|c|c|c|c|c|c|}
\hline \multirow[t]{2}{*}{$\begin{array}{l}\mathrm{f}_{0} \\
(\mathrm{kHz})\end{array}$} & \multirow[t]{2}{*}{$\begin{array}{l}\mathrm{F}_{\mathrm{OL}} \\
(\mathrm{kHz})\end{array}$} & \multirow[t]{2}{*}{$\begin{array}{l}\mathrm{f}_{0} \sim \mathrm{F}_{\mathrm{OL}} \\
(\mathrm{kHz})\end{array}$} & \multicolumn{2}{|c|}{$\begin{array}{l}\text { Gain Roll-off in stop } \\
\text { band }\end{array}$} & \multicolumn{2}{|c|}{$\begin{array}{l}\text { Gain } \\
\text { Stabilization }\end{array}$} & \multirow{2}{*}{$\begin{array}{l}\text { Peak Gain } \\
\text { of } \\
\text { overshoot } \\
\text { dB }\end{array}$} & \multirow[t]{2}{*}{$\begin{array}{l}\mathrm{F}_{\mathrm{OSH}} \\
(\mathrm{kHz})\end{array}$} \\
\hline & & & dB/Octave & $\begin{array}{l}\text { Octave } \\
\text { starting at } \\
(\mathrm{kHz})\end{array}$ & $\mathrm{dB}$ & $\begin{array}{l}\mathrm{F}_{\mathrm{S}} \\
(\mathrm{kHz})\end{array}$ & & \\
\hline 10 & 15.1 & 5.1 & 18.3 & 30 & 0 & 0.5 & 17.4 & 10 \\
\hline 20 & 27.8 & 7.8 & 18.7 & 50 & 0 & 0.5 & 17.3 & 20 \\
\hline 50 & 66.5 & 16.5 & 18.9 & 100 & 0 & 0.5 & 17.47 & 50 \\
\hline 70 & 92.6 & 22.6 & 20 & 115 & 0 & 0.5 & 17.3 & 70 \\
\hline 100 & 151.4 & 51.4 & 18.8 & 200 & 0 & 0.5 & 17 & 100 \\
\hline 150 & 192 & 42 & 18.8 & 300 & 0 & 0.5 & 4.46 & 150 \\
\hline \multicolumn{3}{|c|}{$\mathrm{F}_{\mathrm{OL}}:-3 \mathrm{~dB}$ Frequency } & \multicolumn{3}{|c|}{$\begin{array}{l}\text { Fs: Frequency at which gain } \\
\text { stabilizes }\end{array}$} & \multicolumn{3}{|c|}{ 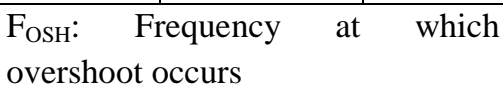 } \\
\hline
\end{tabular}

\section{HIGH PASS RESPONSE}

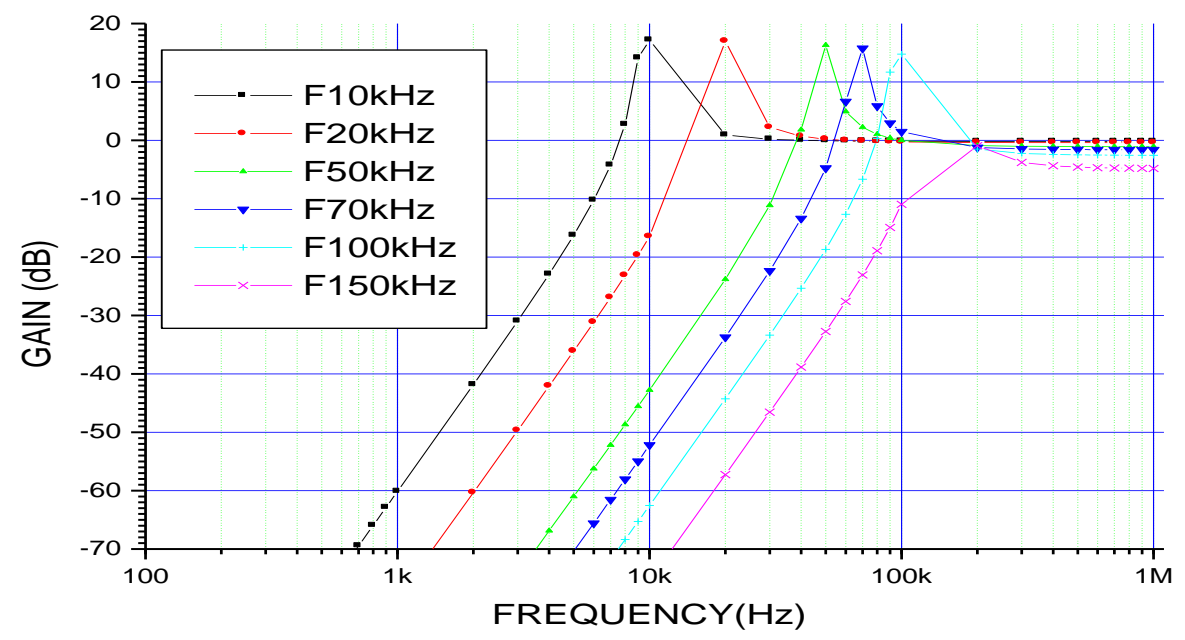

Fig 3.

Table 2: Analysis of High pass response

\begin{tabular}{|c|c|c|c|c|c|c|c|c|}
\hline \multirow[t]{2}{*}{$f_{0}$} & \multirow[t]{2}{*}{$\begin{array}{l}\mathrm{F}_{\mathrm{OH}} \\
(\mathrm{kHz})\end{array}$} & \multirow[t]{2}{*}{$\mathrm{f}_{0} \sim \mathrm{F}_{\mathrm{OH}}$} & \multicolumn{2}{|c|}{$\begin{array}{l}\text { Gain Roll-off in stop } \\
\text { band }\end{array}$} & \multicolumn{2}{|c|}{ Gain Stabilization } & \multirow{2}{*}{$\begin{array}{l}\text { Peak Gain } \\
\text { of } \\
\text { overshoot } \\
\mathrm{dB}\end{array}$} & \multirow[t]{2}{*}{$\begin{array}{l}\mathrm{F}_{\mathrm{OSH}} \\
(\mathrm{kHz})\end{array}$} \\
\hline & & & $\mathrm{dB} /$ decade & $\begin{array}{l}\text { Decade } \\
\text { Starting at } \\
(\mathrm{kHz})\end{array}$ & $\mathrm{dB}$ & $\begin{array}{l}\mathrm{F}_{\mathrm{S}} \\
(\mathrm{kHz})\end{array}$ & & \\
\hline 10 & 7.2 & 2.8 & 19.4 & 5 & 0 & 40 & 17.2 & 10 \\
\hline 20 & 13.2 & 6.8 & 19.9 & 10 & -0.23 & 80 & 16.9 & 20 \\
\hline 50 & 35.9 & 14.1 & 18.5 & 10 & -0.88 & 200 & 16.2 & 50 \\
\hline 70 & 51.5 & 19.5 & 19.1 & 30 & -1.5 & 300 & 15.7 & 70 \\
\hline 100 & 75.2 & 24.8 & 19 & 40 & -2.3 & 300 & 14.8 & 100 \\
\hline 150 & 173.4 & 23.4 & 19 & 40 & -4.3 & 400 & -0.48 & 150 \\
\hline
\end{tabular}




\section{International Journal of Current Science Research and Review}

ISSN: 2581-8341

Volume 04 Issue 10 October 2021

DOI: 10.47191/ijcsrr/V4-i10-23, Impact Factor: 5.825

\section{RESULT AND DISCUSSION}

The circuit performance is studied for different values of Central frequenciesf $\mathrm{f}_{0}(1 \mathrm{k}, 5 \mathrm{k}, 10 \mathrm{k}, 20 \mathrm{k}, 50 \mathrm{k}, 70 \mathrm{k} 100 \mathrm{k}$ and $150 \mathrm{k}$.). with circuit merit factor $\mathrm{Q}=10$.The general operating range of this filter is $10 \mathrm{~Hz}$ to $1 \mathrm{MHz}$.The value of $\beta_{\mathbf{1}}, \beta_{\mathbf{2}}$ and $\beta_{\mathbf{3}}$ is $6.392 \mathrm{X}$ $10^{6}$ for LF $356 \mathrm{~N}$

From figure (2) it is observed that gain stabilizes to $0 \mathrm{~dB}$ at $0.5 \mathrm{kHz}$ for all values of central frequencies. The gain roll-off varies between 18.3 to $20 \mathrm{~dB} /$ Octave. The average gain roll-off is $18.7 \mathrm{~dB} /$ Octave which is close to ideal value of $18 \mathrm{~dB} /$ Octave. From figure (3) it is observed that the gain roll-off value varies between 19 to $19.9 \mathrm{~dB} /$ Octave close to ideal value. Gain stabilizes beyond 40k.Fig (2) and (3) shows the Overshoot in the responses and it occurs at central frequency.

\section{SENSITIVITIES}

The sensitivity equations of $\omega_{0}$ and $Q$ with respect to parameters $k_{1}, k_{2}, k_{3}, \beta_{1}, \beta_{2}, \beta_{3}, g_{0}, g_{1}, g_{2}$ and $g_{3}$ are as given below.It is found that the proposed circuit has very low sensitivity.

$$
\begin{gathered}
S_{K_{1}}^{\omega_{0}}=S_{K_{2}}^{\omega_{0}}=S_{K_{3}}^{\omega_{0}}=\frac{1}{3} \quad, S_{\beta_{1}}^{\omega_{0}}=S_{\beta_{2}}^{\omega_{0}}=S_{\beta_{3}}^{\omega_{0}}=\frac{1}{3} \\
S_{K_{1}}^{Q}=S_{K_{1}}^{Q}=S_{K_{1}}^{Q}=S_{K_{1}}^{Q}=-\frac{(1+Q)}{3} \\
S_{g_{0}}^{\omega_{0}}=-\frac{1}{3}\left(\frac{g_{0}}{g_{0}+g_{1}+g_{2}+g_{3}}\right), S_{g_{1}}^{\omega_{0}}=-\frac{1}{3}\left(\frac{g_{1}}{g_{0}+g_{1}+g_{2}+g_{3}}\right), \\
S_{g_{2}}^{\omega_{0}}=-\frac{1}{3}\left(\frac{g_{2}}{g_{0}+g_{1}+g_{2}+g_{3}}\right), S_{g_{3}}^{\omega_{0}}=\left(\frac{1-g_{3}}{3}\right) \\
S_{g_{0}}^{Q}=S_{g_{1}}^{Q}=0, S_{g_{2}}^{Q}=-(1+Q), S_{\beta_{1}}^{Q}=S_{\beta_{2}}^{Q}=-\frac{1}{3}(1+Q) \\
S_{g_{3}}^{Q}=S_{\beta_{3}}^{Q}=S_{k_{3}}^{Q}=\frac{2}{3}(1+Q)
\end{gathered}
$$

\section{CONCLUSION}

In this paper, a realization of a current mode third order high pass and low pass filter is described. The proposed circuit employs operational amplifier as the basic building unit. The filter circuit can realize transfer functions and circuit characteristics can be electronically tuned. The circuit has passive sensitivities no more than unity. The proposed circuit works ideal for Q $>1$ at central frequency $\mathrm{f}_{0}=10 \mathrm{kHz}$. The gain roll-off is close to $18 \mathrm{~dB} /$ octave. The circuit is suitable for high frequency operation and monolithic integration.

\section{REFERENCES:}

1. Higashimura, M., \Active-R realization of current-mode high pass filter," Int. J. Electronics, Vol. 6, $1279\{1283,1992$.

2. Shinde, G. N. and P. D. Achole, Multiple feedback third order active-R filter with varying tapping ratio," Indian J. Physics, Vol. 80, No. 2, $187\{190,2006$.

3. Shinde, G. N. and P. B. Patil, IThird order active-Rfilter with feed forward input signal," Sadhana Journal of Engineering Science, Vol. 28, No. 6, 1919\{1926, 2003.

4. Tsukutani, T., M. Higashimura, Y. Sumi, and Y. Fukui, IElectronically tunable current mode active-only biquadratic filter," Int. J. Electronics, Vol. 87, No. 3, 307\{314, 2000.

5. Hsu, C. C. and W.-S. Feng, IStructural design of current-mode biquad filters," Int. J. Elec-tonics, Vol. 88, No. 1, 41\{51, 2001.

6. Nandi, R., \Active R realization of bilinear RL impedances and their applications in a high-Q parallel resonator and external oscillator," Proceeding of the Institute of Electrical and Elec-tronics Engineering, 1978.

7. Mitra, A. K. and V. K. Aatre, Low sensitivity high frequency active R filters," IEEE Trans-actions on Circuits and Systems, Vol. 23, 670\{676, 1976.

8. Tskutanio, T., M. Ishida, and Y. Fuksui, ICancellation technique of parasitic poles for active-Rhigh pass filter," Transaction of the Institute of Electronics and Communication Engineering of Japan, Pt. E, Vol. 75, 1083\{1085, 1991. 


\section{International Journal of Current Science Research and Review}

ISSN: 2581-8341

Volume 04 Issue 10 October 2021

DOI: 10.47191/ijcsrr/V4-i10-23, Impact Factor: 5.825

IJCSRR@ 2021

www.ijesrr.org

9. Shah N. A., M. F. Rather, M. A. Malik, and S. Z. Iqbal, ICascadable electronically tunable SITO current-mode activeonly universal filter," Int. J. Electronics, Vol. 8, No. 1, 141\{151,2005\}.

10. Shinde, G. N. and D. D. Mulajkar, International Journal of Physical Sciences, Vol. 3, No. 6,

11. A.K.Singh and R.Senani, Electronics Letters, vol.34, pp. 719-719, 1998.

12. G.W.Roberts and A.S.Sedra, Electronics Letters, vol.25, pp. 759-761, 1989.

13. G.W.Roberts and A.S.Sedra, IEEE Trans.circuits and system. 39, 4, pp 257-263, 1992.

Cite this Article: Dr. D. D. Mulajkar (2021). Frequency Response of Electronically Tunable Current-Mode Third Order High Pass and Low Pass Filter for $Q=10$. International Journal of Current Science Research and Review, 4(10), 1415-1420 